\title{
MDONSAN
}

ISSN $0853-8980$
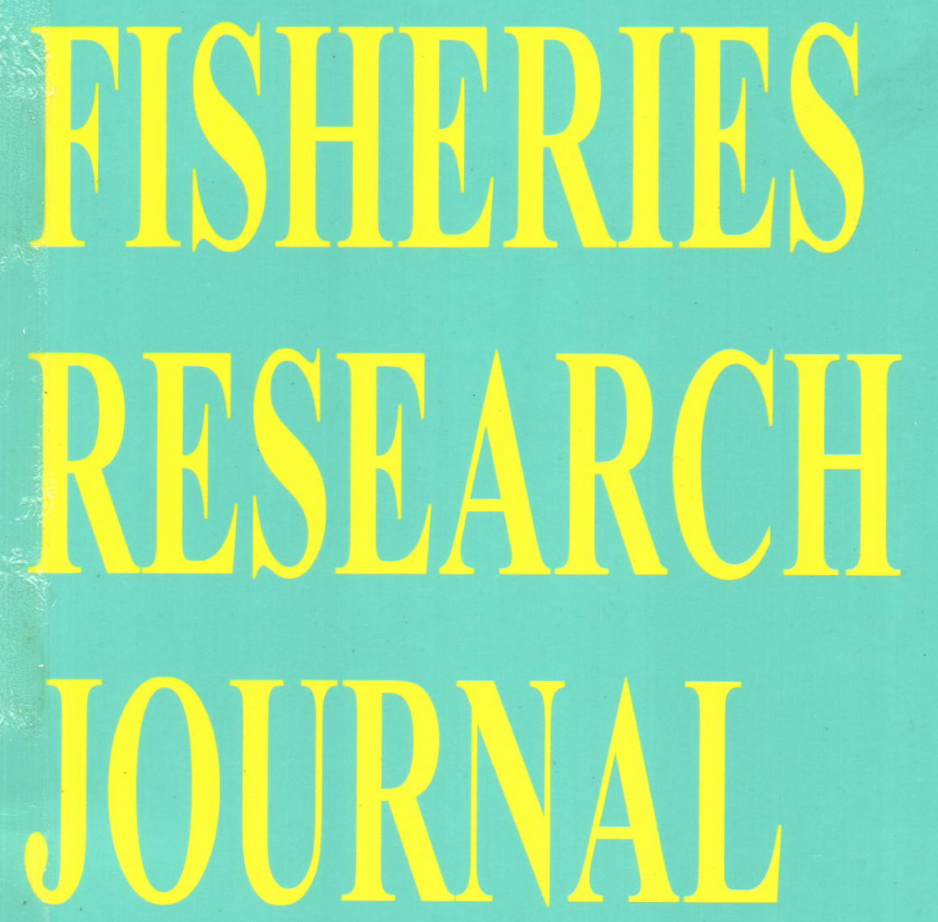


\title{
INDONESIAN FISHERIES RESEARCH JOURNAL
}

\author{
Volume 14 Number 1 June 2008 \\ Acreditation Number: 101/Akred-LIPI/P2MBI/10/2007 \\ (Period: November 2007-November 2010)
}

Indonesian Fisheries Research Journal is the English edition of fisheries research journal. The first published in 1994 with publishing frequently is once a year. Since 2005, this journal published twice on JUNE and DECEMBER.

\section{Head of Editor Board:}

Prof. Dr. Ir. Endi Setiadi Kartamihardja, M.Sc.

\section{Members of Editor Board: \\ Prof. Dr. John Haluan \\ Dr. Ir. Subhat Nurhakim, M.S. \\ Dr. Ir. Wudianto, M.Sc. \\ Dr. Ir. Indra Jaya}

\section{Refrees for this Number:}

Prof. Dr. Ir. Ari Purbayanto, M.Sc. (Bogor Agriculture Institute)

Dr. Ir. Setyo Budi Susilo, M.Sc. (Bogor Agriculture Institute)

Dr. Ir. Augy Syahailatua (Research Center for Oceanography-Indonesian Institute for of Science)

\section{Managing Editors:}

Dra. Endang Sriyati

Arvy Herdianto Firmansyah

Published by:

Agency for Marine and Fisheries Research

\section{Manuscript send to the publisher:}

Indonesian Fisheries Research Journal

Research Center for Capture Fisheries

JI. Pasir Putih I Ancol Timur Jakarta 14430 Indonesia

Phone (021) 64711940

Fax: (021) 6402640

Email: rccf_office@indo.net.id

Indonesian Fisheries Research Journal is published by Research Center for Capture Fisheries. Budgeting F.Y. 2008. 

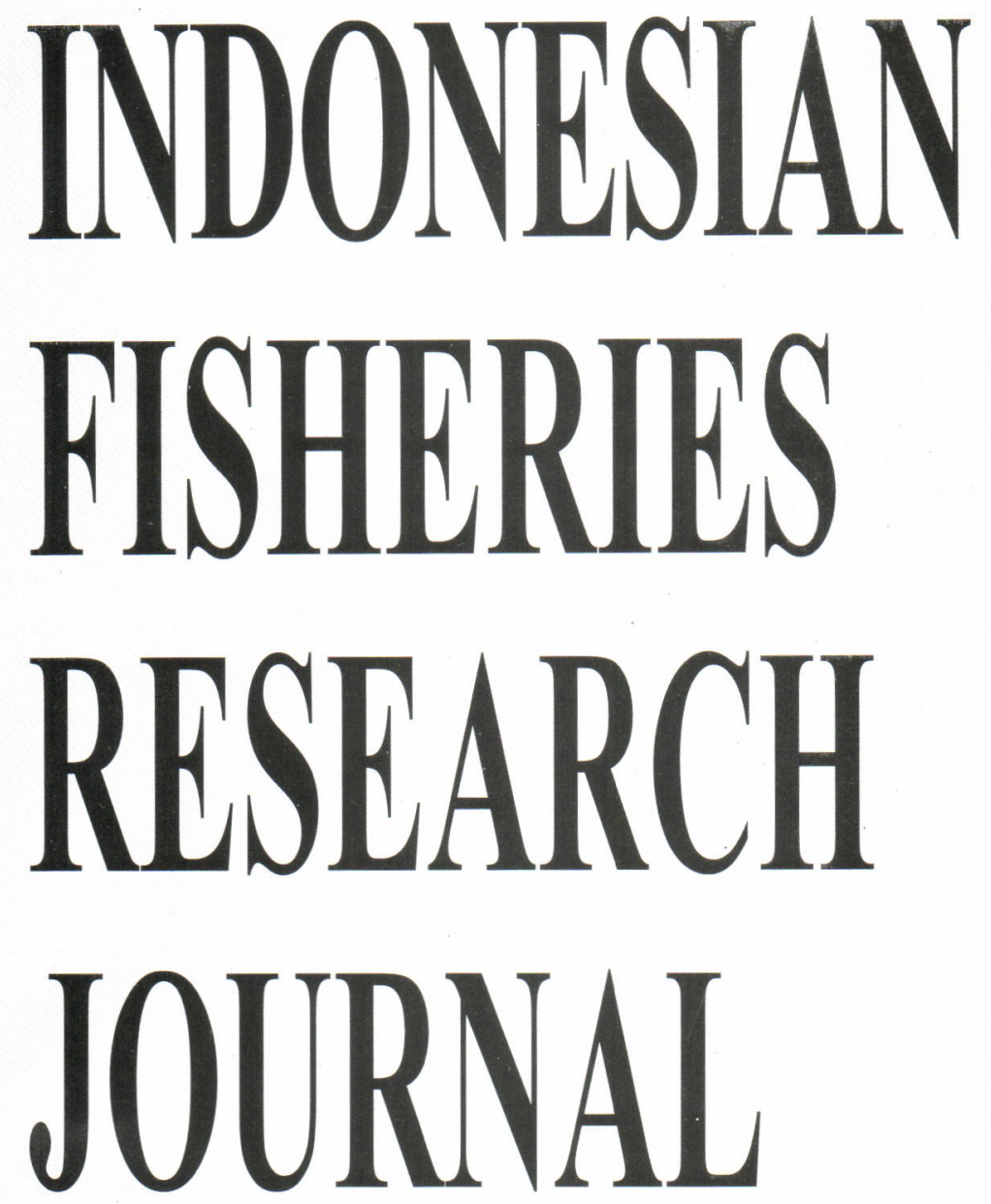

O. AGENCY FOR MARINE AND FISHERIES RESEARCH MINISTRY OF MARINE AFFAIRS AND FISHERIES

\begin{tabular}{|l|c|c|c|c|c|}
\hline Ind.Fish Res.J. & Vol.14 & No.1 & Page 1-49 & $\begin{array}{c}\text { Jakarta } \\
\text { June-2008 }\end{array}$ & $\begin{array}{c}\text { ISSN } \\
0853-8980\end{array}$ \\
\hline
\end{tabular}




\section{PREFACE}

Indonesian Fisheries Research Journal Volume 14 Number 1 June 2008 is the first published of Research Center for Capture Fisheries in 2008. The second number of journal will be published in December 2008. This journal to expand communication among fisheries scientiest entirely part of the country well as other scientific in the tropical countries. This journal is financially supported by the Research Center for Capture Fisheries, budgeting fy 2008.

This volume of the journal compose of sex articles with focused on six articles about sea fisheries resources. They are millenium gillnet in Cirebon, deep sea shrimp resources in the Southern Java, accoustic observation and exploitation of the purse seine in the Java Sea, spatio temporal distribution of small pelagic fish in the Java Sea, aggregation of Holothuria on seagress area of Medana Bay, and estimated unrecorded catch related to the number of licenced fishing vessel in the Arafura Sea.

We would like thanks to the refrees their effort and contribution in review and correcting the manucripts. 


\section{INDONESIAN FISHERIES RESEARCH JOURNAL Vol. 14 No. 1 - June 2008}

\section{CONTENTS}

Page

\section{PREFACE}

CONTENTS

Studies on Capture Process and Fish Behaviour Towards Millennium Gill Net in Bondet Waters, Cirebon

By: Carolina Catur Rakhmadevi, Ari Purbayanto, and M. Fedi A. Sondita

Potential Yield of Deep Sea Shrimp Resources in the Southern Java of the Indian Ocean EEZ Waters

By: Ali Suman, Muhammad Rijal, and Gatut Bintoro

The Accoustic Observation and the Exploitation of the Purse Seine Fishery in the Java Sea

By: Duto Nugroho, Bonar P. Pasaribu, and Vincent P. Siregar

Spatio Temporal Distribution of Small Pelagic Fish in the Java Sea

By:Wijopriono

Aggregation of Holothuria (Metriatyla) albiventer Semper (1868) (Echinodermata: Aspidochirotida) on Seagrass Area of Medana Bay, West Lombok

By: Pradina Purwati, Pitra Widianwary, Sigit Anggoro Putro. Dwiono, and Oktavianto Samir

Estimated Unrecorded Catch Related to the Number of Licensed Fishing Vessel in the Arafura Sea

By: Badrudin, Subhat Nurhakim, and Budi Iskandar Prisantoso 